\title{
Financial reporting consequences of capital xenophobia
}

\author{
David Godsell \\ University of Illinois at Urbana-Champaign
}

The purpose of this editorial is to describe financial protectionism as a potentially important determinant of financial reporting outcomes. Fear of foreign capital, or capital xenophobia, spurs financial protectionism. Examining the effects of financial protectionism on financial reporting outcomes potentially permits an expansion of positive accounting theory and, in particular, the political cost hypothesis. I first describe extant literature examining the political cost hypothesis. I then describe national-security related drivers of capital xenophobia. Next, I examine settings in which we can observe variation in financial protectionism. I conclude by positing varied paths by which financial protectionism can affect financial reporting outcomes. I leave contemplation of audit, tax, compensation, among other accounting outcomes for future consideration.

\section{Positive Accounting Theory \& the Political Cost Hypothesis}

Positive accounting theory has long guided archival researchers to examine determinants of firms' accounting choices (Watts and Zimmerman, 1978; 1986). Within positive accounting theory, the political cost hypothesis predicts that firms will exploit discretion in accounting policies to alter the appearance of profits to minimize (maximize) political costs (benefits). Traditional political costs include excess-profit taxes, price controls, and antitrust enforcement, while traditional benefits include import trade relief. These costs and benefits are economically material wealth transfers to or from the private sector imposed by the government to rectify a perceived socioeconomic inequity. These wealth transfers stem from public concerns about impropriety: foreign goods dumping, excessive profiteering, environmental recklessness, competition suppression, and special interest electioneering. Crucially, the probability and magnitude of these wealth transfers often hinge on the level of firm profits, a measure dependent on firm's accounting choices. 


\section{Political Determinants of Financial Reporting}

Researchers draw support for the political cost hypothesis from many settings. For example, Jones (1991), Magnan, Nadean, and Cormier (1999) and Godsell, Welker, and Zhang (2017) examine accounting choices made by firms that choose to petition for an import relief investigation or an antidumping complaint in the U.S., Canada, and Europe, respectively. Similarly, Lim and Matolcsy (1999) and Navissi (1999) study the accrual choices of firms that request an increase in the permissible price for goods from the Australian Prices Justification Tribunal and firms that apply for price increases in New Zealand after the 1970 Price Freeze Regulation, respectively. Relatedly, Cahan (1992), Johnston and Rock (2005), and Hall and Stammerjohan (1997) study the earnings response of firms undergoing an antitrust investigation; firms potentially violating the Comprehensive Environmental Response, Compensation, and Liability Act (CERCLA); and oil companies undergoing litigation, respectively. Monem (2003) uses the introduction of the Australian Gold Tax as a source of variation in political costs. Key (1997) tests the earnings management response of 24 cable television providers during a period of industry congressional scrutiny. Hao and Nwaeze (2015) examine earnings management by pharmaceutical companies in anticipation of the 2008 presidential election, which proposed major healthcare reform. Ramanna and Roychowdhury (2010) examine outsourcing firms' discretionary accruals around an election in which outsourcing was a major campaign issue. Cahan, Chavis, and Elmendorf (1997) estimate earnings management in anticipation of the CERCLA of 1980 on chemical companies. Boland and Godsell (2019) examine defense firm financial reporting in response to U.S. soldier fatalities that tend to vulgarize war profits.

These studies demonstrate that firms minimize (maximize) political costs (benefits) by altering the appearance of profits. While the large political cost literature supports the prediction that firms use accounting choices to alter the appearance of financial performance to minimize (maximize) political costs (benefits), we know little about a new and potentially important firm attribute-the extent of foreign ownership and, in particular, foreign government ownership - which may determine the level of political costs faced by firms. Political costs plausibly stem from foreign ownership because governments suspect foreign acquirers' motives (Karolyi and Liao, 2017) and because financial protectionism is popular among citizenry (Pew Research Report, 2014; Mayda and Rodrik, 2005). Public concern regarding foreign investment stems from national security fears that 1) acquired technology could be deployed by the acquirer for other than commercial and financial purposes, potentially enabling U.S. rivals, and 2) excessive reliance upon foreign-owned enterprises could render defense contractors vulnerable to supply chain disruptions (Moran, 2009). 


\section{Capital Xenophobia}

Fear of outside capital, or capital xenophobia, stemming from these concerns is a persistent characteristic of U.S. foreign policy. A legislative history offers some insight. The Pickett Act of 1909 enacted limits to foreign claims on western U.S. oil-producing land, Congress authorized the President to restrict foreign investment in the fledgling radio industry in 1912, the Mineral Lands Leasing Act of 1920 limited foreign oil companies' ability to drill in the U.S., the Defense Production Act of 1950 gave the U.S. President the power to reject foreign investments under a state of emergency, the Exon-Florio Amendment of 1988 to the Defense Production Act liberalized the terms under which the U.S. President could reject foreign investment, and the Byrd Amendment of 1993 required rather than permitted the U.S. President to investigate foreign investments when made by a foreign government-controlled entity. In an examination of the European Union setting, Dinc and Erel (2013) identify many examples of host country scuttling of proposed foreign takeovers of domestic firms, even though EU regulation does not permit member states to obstruct foreign investment. Overall, though fear of outside capital is a persistent characteristic of U.S. foreign policy, little is understood about its effects on financial reporting.

Financial reporting effects may result from political motives behind foreign government investment. Some evidence of the use of foreign government investment to meet political objectives already exists. Calluzzo, Dong, and Godsell (2017) find that foreign government investors are attracted to firms engaged in U.S. campaign finance and that firm campaign finance contributions increase after foreign government investment. Their findings are consistent with foreign government efforts to circumvent the constitutional ban on foreign influence in the U.S. political process. In addition, Knill, Lee, and Mauck (2012) and Johan, Knill, and Mauck (2013) find that foreign government investors invest in foreign countries with which the foreign government has weak or deteriorating political relations. These findings are consistent with foreign governments converting economic resources into political capital and potentially explain why announcement returns for foreign government investment are lower than those for other institutional investors (Bortolotti, Fotak, and Megginson, 2015). Because the pursuit of political objectives sacrifices financial and commercial objectives, a possible implication for financial reporting of foreign government investment is that target firm deviation from pre-investment profit levels may signal political objectives. Regulators, for example, may determine that target firms are pursuing political objectives if they detect deviation from a profit objective (e.g., if profits decline). 


\section{Financial Protectionism as a Response to Capital Xenophobia}

Recently, regulatory power to impose political costs on firms suspected of political objectives has grown. Sensitivity to foreign investment is evidenced by new U.S. legislation regulating foreign investment that is being mimicked worldwide. U.S. Congress passed the Foreign Investment and National Security Act (FINSA) in 2009 in response to increasing public concern regarding record amounts of foreign ownership of U.S. firms (Rose, 2014). FINSA codifies the Committee on Foreign Investment in the U.S.s (CFIUS) authority to mitigate national security risks by purging existing foreign investment from U.S. companies, imposing costly restrictions on would-be foreign acquirers, or rejecting proposed foreign takeovers outright. For example, China-based Ant Financials \$1.2 billion bid for MoneyGram and Singapore-based Broadcom Ltd.s $\$ 117$ billion bid for Qualcomm Incorporated were both rejected by CFIUS due to concern about foreign ownership of these firms. Further, CFIUS recently began proceedings to force the Chinese company Beijing Kunlun Tech Co. Ltd. to divest its ownership of the world's largest social networking app for the LGBTQ population, Grindr, which it acquired two years earlier.

In their analysis of FINSA, Godsell, Lel, and Miller (2019) demonstrate that FINSA had a strong effect on U.S. firms. They show that, after FINSA, CFIUS investigations increased dramatically, as did news articles and SEC filing mentions of CFIUS. Godsell, Lel, and Miller also note that all recorded mentions of CFIUS during U.S. earnings conference calls occur during or after the adoption of FINSA. They further report that foreign takeovers decline for U.S. firms more susceptible to these frictions after FINSA, including research intensive firms (by 56 percent) and those with greater ability to disrupt U.S. supply chains (by 36 percent). Firms in industries susceptible to these frictions lose 3.12 percent of their value over a three-day window surrounding nine events related to the passage of FINSA.

As mentioned, governments worldwide have mimicked FINSA-style legislation (Steinitz and Ingrassia, 2009; Rose, 2018; Wall Street Journal 2018). FINSA and copycat legislation present new political costs for firms if regulators, for example, deem deviating from a profit motive evidence of the primacy of a political objective. These costs provide firms with an incentive to orchestrate the appearance of financial performance similar to that which existed prior to foreign investment. This incentive is strongest for firms with foreign government investment because the risk of political objectives determining target firm outcomes is higher for foreign government investment than foreign non-government investment. Consistent with public fear of outside capital and, in particular, foreign government owned and controlled outside capital, major components of FINSA specifically target foreign government investment. Rose $(2014,2)$ writes:

"FINSA has particularly significant effects on investment by sovereign wealth funds (SWFs) and state-owned enterprises (SOEs). Indeed, FINSA is properly understood as a response to SWF and SOE activity, and is designed to provide a framework in which U.S. regulators can weigh the particular risks presented with investment by state-controlled entities." 


\section{Sovereign Wealth Funds}

While SOEs have been extensively studied in the accounting literature, SWFs have received almost no attention, largely due to scarce data availability on SWF investments. SWFs holding approximately $\$ 8$ trillion in assets are investment funds that are directly or indirectly government-owned and -controlled, funded from government assets, and predominantly engaged in cross-border investment activity (Megginson, Yu and Han, 2013). Between 2001 and 2014, SWF assets under management grew at a compounded annual growth rate of 16.2 percent, amounting to $\$ 7.1$ trillion USD in assets by 2014, an amount greater than the global sum of assets held by private equity and hedge funds (Sovereign Wealth Fund Institute, 2014). SWF assets comprise roughly 7 percent of the $\$ 100$ trillion held by the global institutional investor community (Prequin, 2015). SWFs' size and distinctiveness have motivated asset managers to establish dedicated teams catering to SWFs (Fernandes, 2017). In comparison, global financial assets grew at an average annual rate of only 1.9 percent between 2007 and 2013 (McKinsey Global Institute, 2013). Thus, SWFs have grown to be larger investors than hedge funds ( $\$ 2.4$ trillion assets under management (AUM); Chung, 2012), exchange traded funds ( $\$ 2.3$ trillion AUM; PricewaterhouseCoopers, 2014 ) and private equity funds ( $\$ 3$ trillion AUM; Financial Times, 2012). Only pension funds, insurance companies and mutual funds are larger institutional investors than SWFs with AUM of about $\$ 31.5$ trillion, $\$ 24.4$ trillion and \$23.8 trillion, respectively (CityUK, 2012). The pattern of increasing cross-border SWF investment render foreign government investment a potential issue of importance for regulators and financial accounting.

Understanding the effect of ownership on financial reporting is crucial to accounting research and yet no prior work has examined how SWFs' affect target firms' financial reporting. Recent papers examine the financial reporting consequences of non-state foreign institutional investors (e.g., Lel, 2019; Beuselinck, Blanco, and Garcia Lara, 2017; Kim, Miller, Wan, and Wang, 2016; Chhaochharia, Kumar, and NiessenRuenzi, 2012; Ayers, Ramalingegowda and Yeung, 2011), yet none focus on the financial reporting effects following from state-owned foreign investment. Likewise, research examining the financial reporting consequences of firms' political connections is ample. These studies tend to focus on the effect of firm- or manager-level connections with same-country politicians (e.g., Chaney, Faccio, and Parsley, 2011; Leuz and Oberholzer-Gee, 2006). In comparison, we know little about the financial reporting consequences of public concern regarding firms' investor-level connections with foreign governments.

\section{Pathways for Financial Reporting Consequences of Capital Xenophobia}

As mentioned above, the primary reason to anticipate distinct financial reporting consequences of SWF investment are SWFs' competing political and financial objectives. Conflicting objectives can have several consequences for financial reporting outcomes. On the one hand, SWFs focused on political objectives may simply be weak monitors. Weaker monitoring vis-à-vis purely financially motivated institutional investors would permit greater managerial rent extraction that may manifest as larger discretionary accruals. If this weak monitoring hypothesis describes the effect of SWF investment on target firms' financial reporting, then the effect should strengthen predictably in the ability for management to extract rents and when conventional institutional investors hold less equity. It is also possible that financial reporting quality erodes as foreign government investors in the U.S. use accounting choices to orchestrate the appearance of sustained performance after investment. This is a plausible expectation to the extent that performance erosion after SWF investment is a signal of political objectives dominating financial and commercial objectives. 
On the other hand, regulatory scrutiny of foreign investment may drive a relationship between SWF investment and discretionary accruals. SWFs may not directly monitor the firm but may attract increased attention to the firm, creating monitoring externality. Foreign government ownership is, as mentioned, often unwelcome due to concerns that political objectives will override financial objectives, and, consequently, these investments prompt higher levels of regulator and media scrutiny on firm behavior (Balding, 2012; Dinc and Erel, 2013). Regulators will monitor SWF target firms more closely if they are concerned that political objectives will begin to dominate financial and commercial objectives after SWF investment. El Ghoul, Guedhami, and Pittman (2011) support this line of reasoning by showing that Internal Revenue Service audits generate monitoring externalities that constrain insiders' diversionary activities. Such additional scrutiny reduces opportunities for earnings management.

A null hypothesis is also credible because SWFs may emulate the governance and management practices of conventional institutional investors (Clark and Monk, 2017). SWFs' financial objectives may motivate them to deter earnings management such that no change in firm monitoring is discernable after SWF investment. They, like other large shareholders, may deter earnings management through active monitoring (Ferreira and Matos, 2008) or, alternately, through monitoring substitutes. Either way, if SWFs view earnings management as detrimental to shareholder value, they should exercise control rights to inhibit discretionary accruals. If so, we would observe no change in earnings management.

\section{Conclusion}

Overall, capital xenophobia may have significant implications for financial reporting quality. Other outcomes unexamined in this note may be similarly affected. SWF target firms may attempt to persuade peer shareholders and regulators business-as-usual prevails after SWF investment by increasing audit safeguards, financial disclosures, and / or increased managerial incentive alignment through increased equity-based compensation. Alternately, it is an open question whether foreign government investment, subject to greater regulator monitoring, engages in more or less tax avoidance. Overall, foreign government investment is an issue of importance for financial accounting because foreign government investment in the U.S. shows few signs of slowing. Moreover, if empirical evidence renders it necessary, it is time to update our understanding of positive accounting theory to include capital xenophobia as a determinant of financial reporting outcomes because foreign government investment is here to stay.

\section{Acknowledgements}

I am grateful to Christie Hayne, Augusto Sampaio Franco de Lima, and Oktay Urcan for helpful comments on this editorial. 


\section{References}

Ayers, B., Ramalingegowda, S., Yeung, P. 2011. Hometown advantage: The effects of monitoring institution location on financial reporting discretion. Journal of Accounting and Economics, 52(1): 41-61.

Balding, C. 2012. Sovereign wealth funds: the new intersection of money and politics. New York:

Oxford University Press.

Beuselinck, C., Blanco, B. and Garcia Lara, J. 2017. The role of foreign shareholders in disciplining financial reporting. Journal of Business, Finance and Accounting, 44(5): 558-592.

Boland, M. and Godsell, D. 2019. Local soldier fatalities and war profiteers: New tests of the political cost hypothesis. Working paper. University of Illinois.

Bortolotti, B. Fotak, V. \& Megginson, W. 2015. The sovereign wealth fund discount: Evidence from public equity investments. Review of Financial Studies, 28: 2993-3035.

Cahan, S. 1992. The effect of antitrust investigations on discretionary accruals: A refined test of the political-cost hypothesis. The Accounting Review, 67: 77-95.

Cahan, S. 1993. Electric utility income in response to the breakdown at the Three Mile Island nuclear power plant and subsequent political events. Journal of Accounting and Public Policy, 12: 37-63.

Cahan, S., Chavis, B., and Elmendorf, R. 1997. Earnings management of chemical firms in response to political costs from environmental legislation. Journal of Accounting, Auditing and Finance, 12: 37-65.

Calluzzo, P., G.N. Dong and D. Godsell. 2017. Sovereign Wealth Fund Investments and the U.S.

Political Process. Journal of International Business Studies, 48: 222-243.

Chaney, P., Faccio, M. and Parsley, D. 2011. The quality of accounting information in politically connected firms. Journal of Accounting and Economics, 51: 58-76.

Chhaochharia, V., Kumar, A. and Niessen -Ruenzi, A. 2012. Local investors and corporate governance. Journal of Accounting and Economics, 54: 42-67.

Chung, J. (2012, April 12, 2012). Hedge-fund assets rise to record level. The Wall Street Journal.

CityUK. 2012. Fund management. Financial market series. https://www.thecityuk.com/research/.

Accessed 11 November 2014.

Clark, G. and Monk, A. 2017. "Sovereign Development Funds: The governance and management of strategic investment institutions." The Oxford Handbook of Sovereign Wealth Funds. Eds. D. Cumming, G. Wood, I. Filatotchev and J. Reinecke. Oxford University Press.

Dinc, S. and Erel, I. 2013. Economic nationalism in mergers and acquisitions. Journal of Finance, 68:

2471-2514.

El Ghoul, S., O. Guedhami, and J. Pittman. 2011. The role of IRS monitoring in equity pricing in public firms. Contemporary Accounting Research, 28(2): 643-674.

Fernandes, N. 2017. "Sovereign wealth funds: Investment choices and implications around the world." The Oxford Handbook of Sovereign Wealth Funds. Eds. D. Cumming, G. Wood, I. Filatotchev and J. Reinecke. Oxford University Press.

Ferreira, M. and P. Matos. 2008. The colors of investors' money: The role of institutional investors around the world. Journal of Financial Economics, 88: 499-533. 
Financial Times. 2007. Funds that shake capitalist logic. Summers L. July 29. Accessed on September 20, 2015 from http://www.ft.com/cms/s/2/bb8f50b8-3dcc-11dc-8f6a-0000779fd2ac.html\#axzz3jf5WC1HJ

Godsell, D., Lel, U. and Miller, D. 2019. Financial Protectionism, M\&A Activity, and Shareholder Wealth. Working Paper. University of Illinois.

Godsell, D., Welker, M. and N. Zhang. 2017. Earnings management during antidumping investigations in Europe: Sample-wide and cross-sectional evidence. Journal of Accounting Research, 55(2): 407-457.

Johnston, D. and Rock, S. 2005. Earnings management to minimize superfund clean-up and transaction costs. Contemporary Accounting Research, 22: 617-642.

Johan, S., Knill, A., \& Mauck, N. 2013. Determinants of sovereign wealth fund investment in private equity vs. public equity. Journal of International Business Studies, 44(2): 155-172.

Jones, J. 1991. Earnings management during import relief investigations. Journal of Accounting Research, 29(2): 193-228.

Karolyi, A. and Liao, R. 2017. State Capitalism's Global Reach: Evidence from Foreign Acquisitions

by State-owned Companies. Journal of Corporate Finance, 42: 367-391.

Kim, I., Miller, S., Wan, H. and Wang, B. 2016. Drivers behind the monitoring effectiveness of global institutional investors: Evidence from earnings management. Journal of Corporate Finance, 40: 24-46.

Knill, A., Lee, B., Mauck, N., 2012. Bilateral political relations and sovereign wealth fund investment. Journal of Corporate Finance, 18, 108-123.

Hall, S., Stammerjohan, W. 1997. Damage awards and earnings management in the oil industry. The Accounting Review, 72(1): 47-65.

Hao, M. and Nwaeze, E. 2015. Healthcare reform proposal and behavior of pharmaceutical companies: The role of political costs. Accounting Horizons, 29(1): 171-198.

Key, K. 1997. Political cost incentives for earnings management in the cable television industry.

Journal of Accounting \& Economics, 23: 309-337.

Lel, U. 2019. The role of foreign institutional investors in restraining earnings management activities across countries. Journal of International Business Studies, 50(6): 895-922.

Leuz, C. and Oberholzer-Gee, F. 2006. Political relationships, global financing and corporate transparency: Evidence from Indonesia. Journal of Financial Economics, 81: 411-439.

Lim, S., and Matolesy, Z. 1999. Earnings management of firms subjected to product price controls.

Accounting and Finance, 39: 131-150.

Magnan, M., Nadean, C., Cormier, D. 1999. Earnings management during antidumping investigations: Analysis and Implications. Canadian Journal of Administrative Sciences, 16: 149-162.

McKinsey Global Institute. 2013. Financial globalization: Retreat or reset? Global capital markets.

http://www.mckinsey.com/insights/global_capital_markets/financial_globalization.

Accessed 11 November 2014.

Mayda, A., Rodrik, D. 2005. Why are some people (and countries) more protectionist than others? European Economic Review, 49: 1393-1430.

Megginson, W. \& Fotak, V. 2015. Rise of the fiduciary state: A survey of sovereign wealth fund research. Journal of Economic Surveys, 29(4): 733-778. 
Monem, R. 2003. Earnings management in response to the introduction of the Australian gold tax.

Contemporary Accounting Research, 20: 747-774.

Moran, T. 2009. Three Threats: An Analytical Framework for the CFIUS Process. Petersen Institute for International Economics.

Navissi, F. 1999. Earnings management under price regulation. Contemporary Accounting Research, 16(2): 281-304.

Pew Research Center. Faith and Skepticism about Trade, Foreign Investment, Survey. Available at: http:// www.pewglobal.org/2014/09/16/faith-and-skepticism-about-trade-foreign-investment/

Prequin. 2015. The 2015 Prequin Sovereign Wealth Fund Review. Available at https://www.prequin.com/ format/publication/0/1.

Rose, P. 2014. The Foreign Investment and National Security Act of 2007: An assessment of its impact on Sovereign Wealth Funds and State-Owned Enterprises. Working paper. Ohio State University.

Rose, P. 2018. FIRRMA and National Security. Ohio State Public Law Working Paper \#452. Roychowdhury, S. 2006. Earnings management through real activities manipulation. Journal of

Accounting \& Economics, 42: 335-370.

Sovereign Wealth Fund Institute. (2014). Sovereign Wealth Fund Institute. Retrieved January 15, 2014, 2014, from www.swfinstitute.org

Steinitz, M. and Ingrassia, M. 2009. The impact of sovereign wealth funds on the regulation of foreign direct investment in strategic industries: A comparative view. Business Law International, 10: 5-18.

Watts, R. and J. Zimmerman. 1978. Towards a positive theory of the determination of accounting standards. The Accounting Review, 53(1): 112-134.

Watts, R and J. Zimmerman. 1986. Positive Accounting Theory. Prentice-Hall Inc. 